\title{
STUDENTS' ATTITUDE TOWARDS SELF-STUDY: A CASE OF COLLEGE STUDY PROGRAMMES IN SOCIAL SCIENCES
}

\author{
KLIZAITĖ Jūratė, ARLAUSKIENĖ Renata
}

Klaipeda State University of Applied Sciences, Klaipeda, Lithuania

\begin{abstract}
In recent years, the significance of quality in higher education has been emphasised, with special emphasis placed on the opinion of students. The present paper analyses the attitude of college students towards self-study assignments as a factor essential for the development of generic competences, presently related to the widely discussed educational paradigms, such as student-oriented learning, metacognitive study strategies, and holistic personality development. The changes in the educational paradigms and recent fundamental and applied research reveal the importance of student independent work in the study process and the development of abilities necessary for learning, the enhancing of motivation, and the promotion of reflection and critical thinking. A new attitude towards the development of student thinking and the enhancing of their activity has been formed. Students' generic abilities necessary for independent work and relevant for the solution of the problems arising in their professional activity in the future (monitoring, organisation, communication, work in a team, etc.), as well as their learning motivation, are different. Student selfstudy activity is a major integral part of college studies, and it has to be appropriately organised, monitored, assessed, and provided with the most important sources of information and technologies. The research aim is to identify the views of college students on self-study assignments in the process of implementation of study programmes in social sciences. The analysis of the outcomes of the student survey and of the research of other authors is expected to lead to the identification of the weaknesses in the organisation of self-study activities and to contribute to the forecasting of the improvement trends and the development of generic competences that integrate individual knowledge, abilities, and attitudes into a whole and and consciously channel them in the chosen direction.
\end{abstract}

Keywords: College; Competence(s); Self-study; Student; Sudy Programme.

\section{Background}

The challenges of globalisation and modernisation of the contemporary world set new requirements for the study process. In recent years, increasing attention has been paid to the ability of self-directed learning, communication skills, and intellectual and moral qualities. In accordance with Rupšienè and Mažionienè (2011), students' self-study became especially relevant due to the change from the traditional instructional paradigm to a constructivist learning one, where learning provides for learners' intensive independent activity. That is understandable, as one of the factors that affects the success of the studies is the experience of self-study. Educational literature has not yet come to a unanimous opinion about what should be 
considered as self-study. Dictionary of the Lithuanian Language (2006), defines self-study as independently done work. To quote Rajeckas (1999), in the formation of learner's autonomy as a personal quality and his skills for self-study, it is necessary to create the conditions that would naturally encourage one to act independently. An important role is played by teacher who is to encourage learners for self-study, otherwise, it can be viewed by learner as not compulsory. As emphasised by Jovaiša (2007), independence is inseparable from motivation, while the role of teacher is to enhance student motivation to independently look for the ways to act, to apply the possessed knowledge, to combine it, to independently pose research problems, and to solve them. Motivation is a complex construct, particularly as it relates to learning (Daly \& Moira, 2010). The idea of self-study is closely related to the constructivist philosophy which states that knowledge can not be inculcated (given): rather, it is to be mastered (constructed) (Pukelis et al., 2011). Student will be a more succesful learner provided teacher shows him the benefit of the taken course (Čiburienė \& Guščinskienè, 2012). Students‘self-study is understood as the studies of individual modules of a study programme. In the process, students will study the theory of the course in depth, apply it when doing assignments, and analyse scientific literature and papers. On the other hand, student faces a problematic situation: how he should learn in order to master the content of the course and not to lag behind the latest developments in the field, and how to be able to use the latest information and later to apply it to one's professional activity. The way of learning is as important as the content of learning. Self-study can be understood as an independent learner's multiplane activity. The scientific literature relevant for the current research includes articles dealing with the specificity of autonomous activity and generic abilities in university studies (Teresevičienè et al., 2006; Tandzegolskienè \& Pileckaite, 2010; Stasènaite, 2010; Beaumont et al., 2011; Rupšienè \& Mažionienè, 2011; Teresevičienè et al., 2012; Pukevičiūtè, 2012; Dudinskienė \& Žydžiūnaite, 2014). The mentioned researchers investigate aspects of self-study organisation in higher school, the competences of learning to learn, the development of generic abilities through selfstudy, the levels of realisation of self-directed learning and their components, independence and self-study, etc,. however, research in the organisation of self-study that enables students to learn independently in college studies is missing. The view of college students in the area of social sciences on the aspects of selfstudy expression could help to improve the study organisation process in higher education. The following research questions were raised in this study: What is student attitude towards self-study assignments in the process of studies in study programmes in social sciences? What should teacher's activity be focused on to enable student to learn independently? Research focus was the students' attitude towards self-study assignments in the process of studies in study programmes in social sciences. The research aim was to identify the views of college students on self-study assignments in the process of implementation of study programmes in social sciences. 


\section{Theoretical framework of self-study organisation in higher school}

In the studies of higher education, a clear trend can be observed of self-study, independent study, and learning to learn occupying an increasingly greater part of studies. The traditional instructional paradigm is being substituted for a new innovative paradigm directed towards the student-oriented learning methodology: its main principle is learner's active role in the learning process and the promotion of his personal responsibility and independence with the aim of his becoming capable of active, responsible, and independent lifelong learning and improvement (Jakubė \& Juozaitis, 2012). To train students for independent and creative activity is one of the key tasks of higher school. The use of self-study assignments, related to the chosen field of studies, in the study process is an effective way to achieve the intended learning outcomes. Self-study assignments promote the mastering of the content of studies and contribute to the revealing of students' generic skills. Self-study in the study process is the basis of learning which enables student to learn independently, and later, the core of independent learning and self-education in the process of lifelong learning. What predetermines students' self-study? The factors of students' self-study include: 1) student involvement in authentic research projects; 2) specific qualities of the supervisor of self-study, such as the expertise in the research field, the experience, attention, and tolerance; 3) constructive advice and the provision of feedback; and 4) the culture of the independence promotion and maintenance in the institution (Pukelis et al., 2011). The said factors are most closely related to teacher's work and his readiness to inititiate and organise student self-study. On the other hand, in the institutions of higher education, the activity of a competent and innovative teacher is reflected by a chosen educational paradigm whose structure includes the following key characteristics: a democratic style of teaching; the ability to use information technologies that ensure the interactivity of student learning; a wide range of teaching/learning methods used in the teaching process; and a favourable physical, social, and emotional environment ensured during the process of teaching (Daukilas, 2010). For self-study, not only the process, but also the personal qualities of learner, the characteristics of cognitive processes, and the environment which may promote an interaction of several factors are of great importance (Teresevičienè et al., 2006), the environment enables student to study independently, i.e. provides an opportunity to pursue purposeful teacher-controlled activities. Efforts are made to enable students not to merely imitate the textbook and teacher-provided materials, but to seek meaningful knowledge, to reflect, analyse, pose problems, and to independently find answers to problematic questions by means of additional sources of information (Stasėnaitè, 2010). Accordingly, independent learning becomes an integral part of didactic and comes to influence the aspects of self-study organisation. To quote Jatkauskienè (2012), independent learning is purposeful, systematic, independent, and autonomous activity of learner intended to acquire knowledge, to develop imagination, to perceive categories and concepts, and to form one's abilities, skills, and behaviour. The ability to find information and to critically evaluate it becomes more important than the knowledge of facts Herring (1998), Dagienè et al. (2002), Vilkonis \& Barabanova (2010). As stated by Tandzegolskienė and Pileckaite (2010), in the discussions of 
self-study, it is important to take into account an independent personality able to independently initiate learning, to be interested, to raise issues, to look for educational materials, to collect information, and to analyse it. Reinders and Balcikanli (2011) (in Teresevičienè et al., 2012) believe that, to promote students'autonomy in learning, it is important to develop the necessary abilities. On the basis of the constructivism and pragmaticism-based approach to self-study, the authors present eight stages in the selfdirected learning process: 1) indentifying needs; 2) setting goals; 3) planning learning; 4) selecting resources; 5) selecting learning strategies; 6) practice; 7) monitoring progress; and 8) assesment and revision, Self-study in the study process is a pursued goal, a form of work, and a teaching method. Moreover, it is through selfstudy that the research and social-evaluative experience is attained (Šedžiuvienė, 2013).

\section{Methodology}

\section{Sample}

The study was conducted in 2013 to 2014-2015 (No. TMV IF - 014). The study sample was the targeted and convenient. The population of respondents consisted of college students in social sciences (the fields of Education and Management) (a total $n=148$ ), ( $n=95$ of the first and $n=53$ of the second year of studies).

\section{Methods}

The following methods were applied in the study the written survey using theclosed-ended questionnaire, analysis of statistical data by applying the SPSS for Windows 19.0.

\section{Tool}

The questionnaire was developed in compliance with the Methodology of Self-Study by means of e-Tools (Pukelis et al., 2011). It presented major principles of student self-study organisation, common to all study programmes, however, they were specified in accordance with the specificity of the study field. The questionnaire consisted of 32 closed-ended statements. The reliability of the questionnaire (Cronbach a) in the analysed sample was 0.83 . It allowed us to identify the student attitude towards self-study assignments that were related to the chosen study field and that enabled them to learn independently. The scales of the questionnaire included: 1) the students' attitude towards teacher's organisation of self-study assignments; 2) the students' attitude towards the value of self-study assignments; 3) the students' attitude towards selfstudy-related consultations with teachers; 4) the students' attitude towards self-study methods; and 5) the students' ${ }^{6}$ attitude towards the assessment of self-study assignments.

\section{Ethics}

Research was based on principles of diagnostic ethics: benevolence, respect of personality, justice and right to receive precise information. 


\section{Results}

The research sought to identify the attitude of the students of study programmes in social sciences towards self-study assignments. The research findings revealed that the highest standard deviation was found on the scale The Students' Attitude towards the Value of Self-study Assignments (Table 1). As witnessed by the findings, the respondents'attitude towards the value of self-study assignments differed.

Table 1

Attitudes towards self-study assignments: descriptive statistics of the scale

\begin{tabular}{|c|c|c|c|c|c|}
\hline Scales of students ${ }^{6}$ attitudes towards self-study assignments & $\mathbf{N}$ & Min & Max & Mean & $\begin{array}{l}\text { Standard } \\
\text { deviation }\end{array}$ \\
\hline $\begin{array}{l}\text { Students' attitudes towards teacher's organisation of self-study } \\
\text { assignments }\end{array}$ & 148 & 15 & 32 & 25.27 & 3.078 \\
\hline Students' attitudes towards the value of self-study assignments & 148 & 16 & 33 & 26.43 & 3.460 \\
\hline Students' attitudes towards self-study-related consultations with teachers & 148 & 12 & 30 & 22.94 & 3.196 \\
\hline Students' attitudes towards self-study methods & 148 & 12 & 25 & 19.85 & 2.528 \\
\hline Students $^{6}$ attitudes towards the assessment of self-study assignments & 148 & 15 & 33 & 25.88 & 3.002 \\
\hline
\end{tabular}

The lowest standard deviation was on the scale Students 'Attitudes towards Self-study Methods. Hence, the respondents had similar views on self-study methods, however, the lowest mean on the scale (19.9), related to the students' attitudes towards self-study methods, proved that the respondents took rather a negative than a positive view of the methods of self-study.

Table 2

Attitudes towards self-study: scale means in the samples of the first and second year students

\begin{tabular}{|l|c|c|c|c|c|}
\hline \multicolumn{1}{|c|}{ Scales of student attitudes towards self-study } & Year of study & N & Mean & Std. Deviation & Sig. (2-tailed) \\
\hline Students' attitudes towards teacher's organisation of & Year 1 & 95 & 25.31 & 2.925 & 0.81 \\
self-study assignments & Year 2 & 53 & 25.18 & 3.363 & 0.81 \\
\hline Students' attitudes towards the value of self-study & Year 1 & 95 & 26.64 & 3.566 & 0.34 \\
assignments & Year 2 & 53 & 26.07 & 3.263 & 0.32 \\
\hline Students' attitudes toward self-study-related & Year 1 & 95 & 22.98 & 3.174 & 0.82 \\
consultations with teachers & Year 2 & 53 & 22.86 & 3.264 & 0.82 \\
\hline Students' attitudes towards self-study methods & Year 1 & 95 & 19.85 & 2.283 & 0.97 \\
& Year 2 & 53 & 19.86 & 2.941 & 0.97 \\
\hline Students' attitudes towards the assessment of self-study & Year 1 & 95 & 25.88 & 3.080 & 0.99 \\
\hline
\end{tabular}


The analysis of the students' attitudes towards self-study assignments in the samples of the first and second years of studies did not reveal any statistical meaningfulness of the said difference (Table 2). As witnessed by the findings, the attitudes of the first and second year students towards self-study did not differ $(\mathrm{p}<0.05)$.

To establish whether the students' attitudes towards self-study differed depending on different study programmes (in the fields of Education and Management), the analysis of variance (ANOVA) was applied. By means of Bonferroni correction, pairwise comparisons were performed between the scales of the student attitudes towards self-study.

Table 3

Attitudes towards self-study: comparison of scale means by study fields of education and management

\begin{tabular}{|c|c|c|c|c|c|c|}
\hline Scales of stude & $\begin{array}{c}\text { The field of the study } \\
\text { programme }\end{array}$ & Mean & $\begin{array}{c}\text { Std. } \\
\text { Deviation }\end{array}$ & df & $\mathbf{F}$ & $\mathbf{p}$ \\
\hline $\begin{array}{l}\text { Students' attitudes towards teacher's organisation } \\
\text { of self-study assignments }\end{array}$ & $\begin{array}{l}\text { Management } \\
\text { Education }\end{array}$ & $\begin{array}{l}25.09 \\
25.85\end{array}$ & $\begin{array}{l}3.100 \\
2.975\end{array}$ & 146 & 1.588 & 0.210 \\
\hline $\begin{array}{l}\text { Students ' attitudes towards the value of self-study } \\
\text { assignments }\end{array}$ & $\begin{array}{l}\text { Management } \\
\text { Education }\end{array}$ & $\begin{array}{l}26.13 \\
27.47\end{array}$ & $\begin{array}{l}3.374 \\
3.594\end{array}$ & 146 & 4.001 & 0.047 \\
\hline $\begin{array}{l}\text { Students' attitudes towards self-study-related } \\
\text { consultations with teachers }\end{array}$ & $\begin{array}{l}\text { Management } \\
\text { Education }\end{array}$ & $\begin{array}{l}22.78 \\
23.47\end{array}$ & $\begin{array}{l}2.967 \\
3.870\end{array}$ & 146 & 1.191 & 0.277 \\
\hline Students $^{6}$ attitudes towards self-study methods & $\begin{array}{l}\text { Management } \\
\text { Education }\end{array}$ & $\begin{array}{l}19.67 \\
20.47\end{array}$ & $\begin{array}{l}2.560 \\
2.351\end{array}$ & 146 & 2.618 & 0.108 \\
\hline $\begin{array}{l}\text { Students' attitudes towards the assessment of self- } \\
\text { study assignments }\end{array}$ & $\begin{array}{l}\text { Management } \\
\text { Education }\end{array}$ & $\begin{array}{l}25.64 \\
26.67\end{array}$ & $\begin{array}{l}2.828 \\
3.452\end{array}$ & 146 & 3.111 & \begin{tabular}{|l|}
0.080 \\
\end{tabular} \\
\hline
\end{tabular}

The results of the analysis revealed that the difference in the attitudes towards self-study of the students from the study programmes in the fields of Education and Management were statistically meaningful on the scale Students ' attitudes towards the value of self-study assignments $(\mathrm{p}=0.047)$ (Table 3$)$. The obtained results suggested that the students of the study programmes in the field of Education took a more positive view of the value of self-study assignments than their peers from the study programmes in the field of Management. Moreover, even though the statistically meaningful correlation was not established, a statistical trend was observed with respect to the views of the students of the study programmes in the fields of Education and Management of the assessment of self-study assignments $(\mathrm{p}=0.08)$. As proved by the results, the students of the study programmes in the field of Education took a more positive view of the assessment of self-study assignments than those of their peers from the study programmes in the field of Management. 


\section{Discussion}

Scientific discussions on teaching/learning in higher school are based on the contemporary conception of studies, a holistic approach, and student experience. The findings of the conducted research and its conclusions encourage the continuation of the research and the discussion of the view of college students from different field study programmes on the principles of self-study organisation in higher school.

The analysis of the student survey results revealed how the students assessed self-study assignments and simultaneously identified some problematic fields in the organisation of self-study activities; the identification shall provide teacher with an opportunity to appropriately deal with the weaknesses of the academic process and shall help student to develop generic competences.

The present research proved that the students of education took a more positive view of the value and assessment of self-study assignments than the students of management. More attention should be pay to the ways of motivated involvement of students in the studies of the chosen theme and to the provision of value to the knowledge, abilities, and skills acquired in the self-study activities. As advised by Pukelis and Savickienè (2011), in the process of self-study, students ought to be given both formative and summative asessment. The formative assessment is especially significant: when applied in the study process, it helps to critically assess the achievements of the studies or the results of professional activity. The summative assessment helps to summarise student achievements. It is well know that assesment defines the higher education curriculum in students' eyes (Ramsden, 2003), and has a major influence on their learning (Biggs, 2003), being viewed as a more powerful driver than teaching in determining what student do and how they do it (Beaumont et al., 2011).

The results of the empirical research allowed to identify students' more negative than positive attitude towards the self-study methods and their variety; consequently, teachers ought to pay more attention to the ways of encouraging students to study independently and thus to more successfully organise the process of studies in higher schopol. Important aspects were highlighted in the analysis of the research by Gedvilienè et al. (2012): for the development of students' generic abilities in the process of self-study, study methods based on project and team work principles, the focus on problem solution, and simulation of authentic situations were of particular importance as they emphasised student independence. In that way, interpersonal competences, the ability to solve problems and to take decisions, leadership, persistence, and the will to win were developed. The organisation of both student individual and increasingly important group self-study activities was facilitated by contemporary educational technologies. They provided an opportunity to radically reform the components of self-study motivation, activity, and assessment. On the other hand, according to Teresevičienè et al. (2012), students who failed to master the fundamental concepts rarely became independent learners. The research conducted by Bobrova et al. (2012) revealed that the in-depth approach to studies was developed by rational learning and teaching methods that promoted student activity, independence in the study process, clearly expressed expectations, and teacher's responsibility for the quality 
of teaching. The way of learning was as important as the content of learning (Čiburienė \& Guščinskienè, 2012).

\section{Conclusions}

The self-study in the learning process is the basis of learning which enables student to learn independently, and later, the core of independent learning and self-education in the process of lifelong learning. The characteristics of student self-study organisation in higher school include the following elements: teacher's organisation of self-study activities, the value of self-study activities, teacher's consultations to discuss the self-study assignments, the diversity of methods, and the objectivity of assessment.

The statements provided by the evaluation from among all the self-study organisation elements in higher school, the students of social sciences were inclined to take a more negative than positive view of the selfstudy methods that directed learner to certain parts of the teaching content in order to better master them. The way of learning is as important as the content of learning. The attitudes of the first and second year students of social sciences towards self-study did not differ, but the students of the study programmes in the field of education took a more positive view of the value of self-study assignments and teachers' assessment of selfstudy assignments than the students of the study programmes in the field of management. Thus, this is a very important the students the development of abilities necessary for learning, the enhancing of motivation, and the promotion of reflection and critical thinking.

\section{References}

Beaumont, Ch., Doherty, M. O., \& Shanonn, L. (2011). Reconceptualising Assessment Feedback: a Key to Improving Student Learning? Studies in Higher Education, 36(6), 671-687.

Bobrova, L., Grajauskas, L., \& Alūzas, R., (2012). Mokymo ir mokymosi kokybės ižžalgos: universitetinių kūno kultūros studiju programos studentų vertinimo kontekstas. Studijos šiuolaikinèje visuomenèje. Mokslo darbai, $3(1), 30-37$.

Čiburienè, J., \& Guščinskienè, J. (2012). Mokymo(si) metodų ir stilių dermė aukštojoje mokykloje. Studijos šiuolaikinèje visoumenèje. Mokslo darbai, 3(1), 38-44.

Daly, L. A., \& Moira, A. P. (2010). Student‘s Approaches to Learning and their Performance in the Extended Project Pilot. The Curriculum Journal, 21(2), 179-200.

Daukilas, S. (2010). Inovatoriškų dèstytojų edukacinių technologijų bruožai. Management Theory and Studies for Rural Business and Infrastructure Development, 5(24), 45-54.

Dudinskienè, L., \& Žydžiūnaitè, V. (2014). Savivaldaus mokymosi stiprybės ir silpnybės savarankiškai studijuojant socialinių mokslų magistrantūroje. Profesinès studijos: teorija ir praktika, 14, 126-132.

Gedvilienè, G., Teresevičienè, M., Žydžiūnaitè, V., \& Kaminskienè, L. (2012). Development of Generic Skills in Self Learning Process in Higher Education School. Applied Research in Health and Social Sciences: Interface and Interaction, 1(9), 17-28.

Dabartinès lietuviu kalbos žodynas (2006). Vilnius: Lietuvių kalbos institutas. 
Jakubè, A., \& Juozaitis, A. M. (2012). Bendruju kompetenciju ugdymas aukštojoje mokykloje. Metodinès rekomendacijos. Vilnius: Vilniaus universitetas.

Jovaiša, L. (2007). Enciklopedinis edukologijos žodynas. Vilnius: Gimtasis žodis.

Inovatyviu destymo ir studijavimo metodų taikymo studiju procese metodologiniai pagrindai (2010). Metodologinis vadovas (Savickienè, I., Pilečikienė, N. ir kt.). Kaunas: Kauno Vytauto Didžiojo universiteto leidykla.

Pukevičiūtè, V. J. (2012). Pirmo kurso studentų mokymosi mokytis kompetencijos sudedamujų dalių dermès tendencijos. Pedagogika, 10(5), 46-45.

Rajeckas, V. (1999). Mokymo organizavimas. Kaunas: Šviesa.

Rupšienè, L., \&Mažionienè, A. (2011). Savarankiškas darbas aukštojoje mokykloje socialinio pedagogo vadybinių kompetencijų ugdymo požiūriu: studentų nuomonè. Tiltai, 3, 151-158.

Megon, K., \& Henk., H. (2011). Exploring the Combincol Relationship of Student and Teacher Factors on Learning Approaches and Self-directed Learning Readiness at a Malaysian University. Studies in Higher Education, 36(2), 185-208.

Stasènaitè, V. (2010). Kolegijos bibliotekos mokymosi aplinkos raiška studentų savarankiškų studijų procese. Profesinès studijos: teorija ir praktika, 7, 111-112.

Tandzegolskienè, I., \& Pileckaitė, R. (2010). Socialinių mokslų srities studentų savarankiškos veiklos raiška universitetinèse studijose. Pedagogika, 97, 43-49.

Savarankiško studijavimo panaudojant E - priemonès metodika. Metodika. (Pukelis, K., Savickienė, I. ir kt.). (2011). Kaunas: Kauno Vytauto Didžiojo universiteto leidykla.

Šedžiuvienè, N. (2013). Studentų savarankiško darbo inovaciniai aspektai. Profesinès studijos: teorija ir praktika, 12 , 135-139.

Teresevičienè, M., Gedvilienė, G., \& Zuzevičiūtė, V. (2006). Andragogika. Kaunas: Kauno Vytauto Didžiojo universiteto leidykla.

Teresevičienè, M., Kaminskienė, L., \& Žydžiūnaitė, V. (2012). Savimoka ir savarankiškas mokymasis aukštojoje mokykloje: kritinè diskurso analizè. Acta Paedagogica Vilnensia, 12, 47-60.

Vilkonis, R., \& Barabanova, I. (2010). Vidurinès mokyklos mokinių savarankiško mokymosi patirtis nuotolinio ir elektroninio mokymo(si) poreikio analizès kontekste. Mokytoju ugdymas, 14(1), 121-136. 